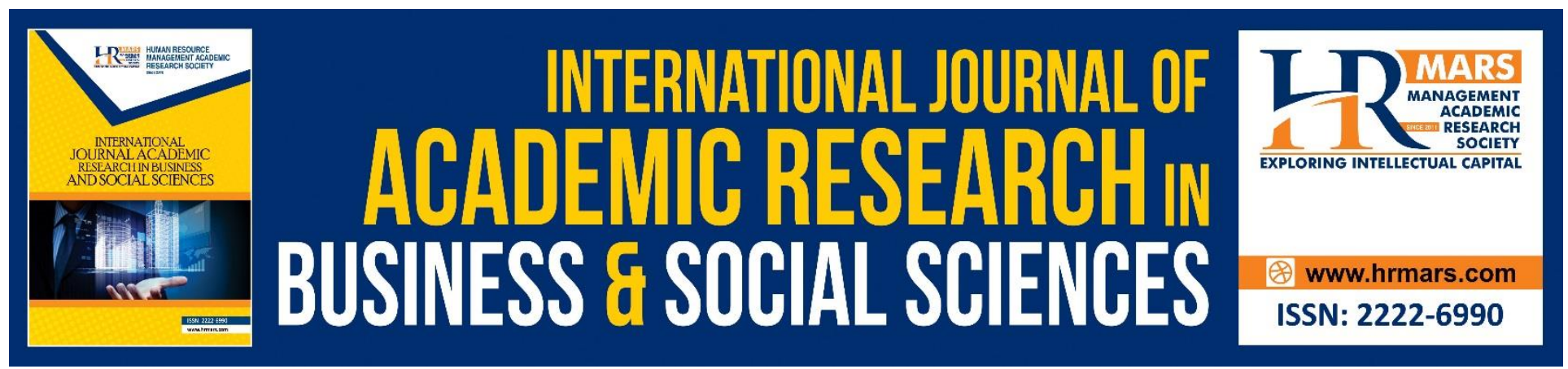

\title{
Human Emotion in Adversity: A Quranic Discourse Coherence Analysis
}

\section{Suzana Sulaiman}

To Link this Article: http://dx.doi.org/10.6007/IJARBSS/v10-i7/7422

DOI:10.6007/IJARBSS/v10-i7/7422

Received: 27 April 2020, Revised: 25 May 2020, Accepted: 16 June 2020

Published Online: 29 July 2020

In-Text Citation: (Sulaiman, 2020)

To Cite this Article: Sulaiman, S. (2020). Human Emotion in Adversity: A Quranic Discourse Coherence Analysis. International Journal of Academic Research in Business and Social Sciences, 10(7), 330-353.

\section{Copyright: (C) 2020 The Author(s)}

Published by Human Resource Management Academic Research Society (www.hrmars.com)

This article is published under the Creative Commons Attribution (CC BY 4.0) license. Anyone may reproduce, distribute, translate and create derivative works of this article (for both commercial and non-commercial purposes), subject to full attribution to the original publication and authors. The full terms of this license may be seen

at: http://creativecommons.org/licences/by/4.0/legalcode

\section{Vol. 10, No. 7, 2020, Pg. $330-353$}

Full Terms \& Conditions of access and use can be found at http://hrmars.com/index.php/pages/detail/publication-ethics 


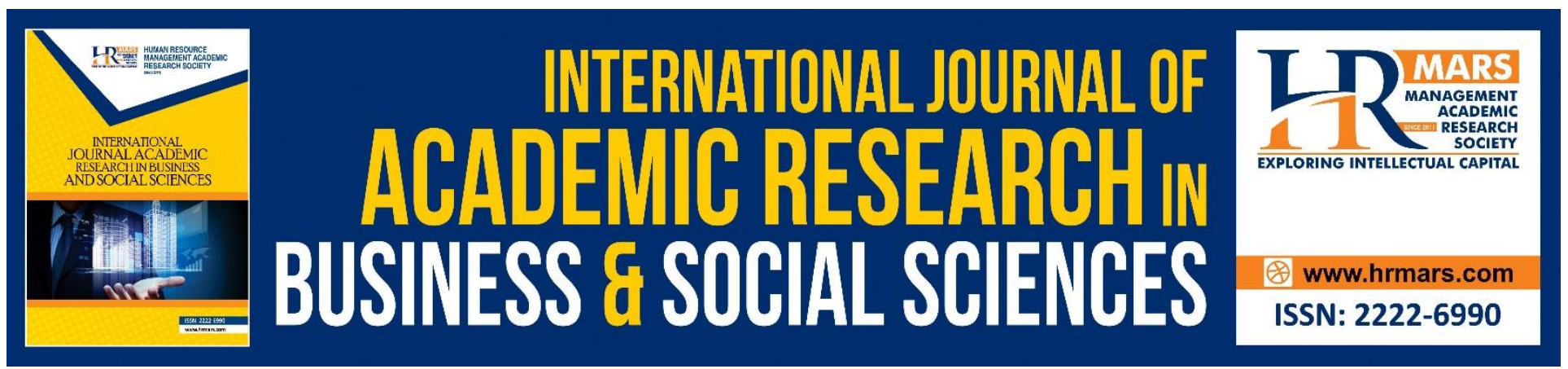

\title{
Human Emotion in Adversity: A Quranic Discourse Coherence Analysis
}

\author{
Suzana Sulaiman \\ Faculty of Languages and Communication, Universiti Sultan Zainal Abidin, \\ Email: suzana@unisza.edu.my
}

\begin{abstract}
The present study attempts to explore the human emotion in adversity, their responses, and the relationship between these responses to the human psychological trait from the framework of Quranic discourse. Despite a growing interest in discourse analysis-based research on the Holy Quran, there is still a scarcity of this type of study. This current work takes a step to fill in this gap to whether the Quranic text displays conceptual and intertextual chaining in terms of the selected Quranic texts. To determine the thematic structural coherence between Quranic texts, textual analysis is applied. The methodology of this study is conducted based on Quranic conceptual, intertextual, and linguistic analysis, adopted from the work of Quranic linguists Hussein Abdul-Raof, that provides an in-depth textual analysis of Quranic discourse. To exemplify, this study has selected a representative sample of Quranic texts with the assistance of Quranic lexicography and Quranic Arabic Corpus (http://corpus.quran.com). The findings highlighted that on the macro-level analysis, the coherence is encountered within the same surah level. On the micro-level analysis, the coherence between Quranic samples encountered from inter-ayah levels, grammatical-morphological level, and semantic level. Also, the thematic structural coherence between Quranic texts is detected.
\end{abstract}

Keywords: Quranic Intertextuality, Emotion, Textual Analysis, Coherence, Discourse.

\section{Introduction}

Recently, the interest of scholars in Quranic discourse tends to mount. For instance, Adel and Maasoum (2011) reflected critically to the Quran as intertext, Galadari, (2013) explored Qur'anic interpretation through the use of intertextual polysemy, and Khawaldeh (2017) analyzed a case study of two Quranic lexemes. Since years, scholars such as Hussein Abdul-Raof drew attention in Quranic discourse study with his great publication efforts commencing from 2004, until 2019 with his latest ideas in Text linguistics of Qur'anic discourse: An analysis. It is believed that Abdul-Raof is pioneering the discussion of Quranic discourse coherence, as demonstrated by Consonance in the Quran.

This current study, however, will be dealing with the Quranic discourse coherence, focusing on the human emotion in the adversity as the major theme. Defining emotion is not easy. Emotion might be a complex psychological state of how human experience and its reaction are subjected to change 
INTERNATIONAL JOURNAL OF ACADEMIC RESEARCH IN BUSINESS AND SOCIAL SCIENCES Vol. 10, No. 7, July, 2020, E-ISSN: 2222-6990 @ 2020 HRMARS

depends on the individual. Also, emotion may be understood as a physiological response, or the body reaction to the emotion, and how well the way human behaves in response to the emotion itself or behavioral response. Ekman (2005) has listed six basic emotions experienced by humans: fear, disgust, anger, surprise, happiness, and sadness. The next batch of basic emotions is expanded to embarrassment, excitement, contempt, shame, pride, satisfaction, and amusement.

As we are aware, the discussion of emotion in the framework of the Quran is not being taken into consideration. Karen Bauer raised the issue of this gap of knowledge, as presented a new method of analyzing emotion in the Quran through Emotional Plots. Thus, she exemplified this 'emotional plot' with three different types of narrative or textual units. i) The story of Joseph, in Surah Yusuf (Q12). ii) a promise-and-threat passage, from Surah al-'Asr (Q103). iii) A story of a people vanquished by God or the believers in Surah al-Shams (Q91). It is noted that Emotional Plots are not necessarily narrative, and that may not even use emotional language. In other words, it is an emotional journey function to engage the attention of the Qur'an's audience, to encourage them to correct belief and action (Bauer, 2017, p. 16-22).

The climax of the present study is to list down the theme reiteration of human emotion and their responses towards hardship, in the realm of Quranic samples. This relates to the emergence of coherence, cohesion, and intertextuality in the selected text. Relationship between cohesion and coherence are suggested by Reinhart, as cited by Wang (2014), coherence is formed from connectedness, consistency, and relevance. So, the sentences in a text are interconnected with each other without contradiction between the propositions and bound with the text in terms of the semantics and grammar. Thus, coherence is not separated from cohesion but is conflated with it.

According to Halliday and Hassan, the notion of cohesion refers to "relation of meaning that exist within the text, ... some forms of cohesion are realized through the grammar and others through the vocabulary" (1976, p. 5 - 6). Similarly, Van Dijk (1980, p. 52) distinguished between two kinds of coherence: local coherence and global coherence. Local coherence involves semantic relations between sentences of a textual sequence. Global coherence is defined as the "theme" or "gist" of a discourse. It is noted that both researchers discussed the relationship of meaning within the text.

Another term regarding the relationship with other texts that share common characteristics is intertextuality. Sulaiman (2011) in her unpublished doctoral dissertation suggested that the term intertextuality in the contact of the Quran can also be replaced with the term Mutashabihat, a similar ayah stylistically reoccurred in some parts of the Quran. This is the same phenomenon stated by Abdul-Raof (2004) as a repetition of motifs, which achieves the textual features of the linguistic function of intertextuality. Hence, it should not be confused with the notion of Ayahs Mutashabihat in Quranic studies, that pairs of Ayahs Muhkamat in the Quran. Citing al-Zarkashī (1988, p. 146), Sulaiman (2011, p. 27) asserts it as:

"...The term signifies an identical concept contributed between two distinct ayahs at least, which stylistically and structurally different but share the same theme. In other words, these ayahs may vary in patterns of each occurrence in different sūrahs". 
The selected Quranic texts in this study are examined from standards of textuality as proposed by De Beaugrande and Dressler (1981), as follows: i) On the macro-level analysis, the notion of coherence is considered as the bigger outer framework of Quranic discourse, ii) On the micro-level analysis, the notion of cohesion concerns grammatical cohesion and lexical cohesion, and iii) the notion of intertextuality.

\section{Methodology}

The data of the current study are outlined from different surahs scattered in the whole Holy Quran. First, these data are extracted manually from Quranic lexicography by Abd al-Baqi (2007). The keyword human is translated literally as the Arabic terms insan. As a result, 65 Quranic texts are encountered. The next step is to pick out the Quranic texts involving any kind of human behavior, personal traits, human characteristics lexically, and semantically. By screening selection through semantic signals, the search data is roughly narrowed down to 20 Quranic texts from 10 Quranic surahs.

The Quranic translation is excerpted from one reference only: The Qur'an: Saheeh International: Arabic Text with Corresponding English Meanings. Purposely, it is to preserve the consistency of the meaning, considering its user friendly and easy to use. The Quranic Arabic Corpus (http://corpus.quran.com) is implied in the analysis of selected data. The approach of data analysis of this study is guided by Abdul-Raof's works in Quranic discourse coherence as he promised: "to investigate how a given Quranic text is made concerning other Qur'anic texts and the intertextual meaning relations among these texts" (Abdul-Raof, 2005, p. 13). Regarding human emotion responses in adversity, the methodology of the current study predominantly is to investigate the conceptual relatedness and textual connectivity among the selection of Quranic data at the macro level and micro-level analysis, as below:

1) The macro-level analysis consists of the discussion of coherence between different surahs, and coherence within the same surah level.

2) The micro-level analysis discusses the selection of Quranic samples from inter-and intraayah levels, context level, word level, phrase level, grammatical-morphological level, and semantic level.

Then, thematic analysis is utilized to determine the thematic structural coherence between Quranic texts.

\section{Data Analysis}

Since the Glorious Quran is originally Arabic, some of the texts are mentioned in Arabic first then translations are mentioned respectively. As aforementioned, 65 Quranic texts related to the term alInsan were recognized throughout the sampling process. Considering through the selected data drawn from the whole Quran, 20 Quranic texts from ten (10) surahs are single out as undermentioned: Q4:28, Q10:12, Q11:9, Q11:10, Q17:11, Q17:67, Q17:83, Q17:100, Q21:37, Q30:33, Q30:36, Q39:8, Q39:49, Q41:49, Q41:50, Q41:51, Q42:48, Q70:19, Q70:20, and Q70:21. These samples, however, are supported by few additional Quranic texts which relate to the matter of intertextuality.

The present study divides the discussion into three major partitions to define a brief significant of the human in the Quranic discourse, as well as to describe the notion of adversity and hardship in the 
realm of this kind of discourse is about. Eventually, on how the Quranic demonstrated the human emotions and their experiences in the facing of the calamity. Interestingly, the implementation of the analysis is combined thematically, semantically, and linguistically to achieve the conceptual chaining and textual progression of intertextually.

\section{Findings and Discussion}

\section{The Notion of Adversity in the Quranic Discourse}

Adversity may occur physically, mentally, emotionally, socially, spiritually, or financially. To understand the notion of adversity in the realm of Quranic discourse, one may not refer to those notions literally to dictionaries. Since the occurrence of adversity in the framework of the Quran is implicitly woven to the stylistic of the Quran and most of the time is thematically embroidered. In a nutshell, emotion is about feeling. This study will scrutinize kinds of human emotion that dominant in adversity, and how the Quran demonstrates their responses semantically, stylistically, and intertextually in textual coherence.

Lexically, these samples are extracted from 20 Quranic texts within ten (10) surahs. It is believed that it expressed affliction as the followings:

1. Keyword d-r-r and its derivation: \{al-durru\} [affliction] in Q10:12; \{durrun\} [adversity] in Q30:33, Q39:8, Q39:49; \{darra'a\} [hardship] in Q11:10, Q41:50;

2. Keyword sh-r-r and its derivation: $\{a l-s h a r r u\}$ [evil] in Q17:83, Q41:49, Q41:51, Q70:20;

3. Keyword s-y-a and its derivation: \{sayyi'atun\} [evil] in Q30:36, Q42:48; \{al-sayyiatu\}[ Bad times] in Q11:10.

Just because the study does not explicitly cite the reference made to Quranic exegesis in interpreting such ayahs, it does not mean the importance of these exegetes is put aside. The reference to exegetes has implicitly alluded throughout the study as an instrument to comprehending the selected Quranic texts. Exegetically, one may find it easier to grasp the implicit meaning of this kind of adversity from the Quranic exegesis. Besides the support of Quranic exegetes, the purpose of the study, however, is more to bring forward the new approach of understanding the Quranic ayahs. That is demonstrated the notion of coherence thematically, semantically, and grammatically, through investigation of conceptual connectivity and intertextual chaining that hold between Quranic surahs and Quranic ayah, in regards to the notion of human emotion and his responses towards adversity. Abdul-Raof $(2005$, p. 25) nominated this notion with the term consonance, instead of the term coherence applied by Modern European Linguistics. To balance, throughout the study, both terms consonance and coherence will be utilized interchangeably.

\section{The Quranic Presentation of Human Emotion in Calamity}

This section will be demonstrating how the human experience obstacles from Quranic discourse in textual analysis. Considering Quranic exegesis as the Quranic vocabularies of interpretation, the point of discussion is supported by al-Razi (2008a, 2008b, 2008c), Ibn Kathir (1986), and al-Qurțubi (1993). Throughout the investigation, three research questions will be examined.

\section{Research Questions}

1. What are the 'basic' human emotions in the time of calamity encountered in the Quran?

2. How does human response when they are afflicted by any kind of calamity? 
INTERNATIONAL JOURNAL OF ACADEMIC RESEARCH IN BUSINESS AND SOCIAL SCIENCES

Vol. 10, No. 7, July, 2020, E-ISSN: 2222-6990 @ 2020 HRMARS

3. Is there any relationship between human responses in adversity with the human psychological traits?

This section comprized the answers of these research by three patterns of Quranic presentation:

\section{Pattern 1: Conceptual and Intertextual Chaining at Inter-Ayah Level}

This section will be discussing a micro textual analysis of the notion of coherence in the Quranic discourse, regarding human emotion in a time of affliction. In other words, Inter-Ayah consonance means the logical connection between two consecutive ayahs. This study will exhibit how these ayahs correlated conceptually and intertextually. This pattern will analyze 8 sets of samples from the extracted data, clustered as: Example 1 [Q30:33-34], Example 2 [Q39:8 -9], Example 3 [Q39:49-52], Example 4 [Q10:11-12], Example 5 [Q41:49-51], Example 6 [Q11:9-10], Example 7 [Example 7: Q70:19-21], and Example 8 [Q17:11, 67, 83 and 100].

\section{Example 1: Q30:33-34}

Q30:33 cited,

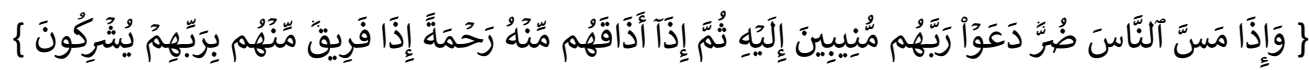
[And when adversity touches the people, they call upon their Lord, turning in repentance to Him. Then when He lets them taste mercy from Him, at once a party of them associate others with their Lord].

In Q30:33, human occurs in plural term al-Nas, formed in accusative masculine plural noun, means people. Thematically, it relates to disbelievers. We believe that it is related to the phrase at the end of the ayah, spotted by the combination of these phrases: birabbihim yushrikūn. The former part comprises three items: i) prefixed preposition (bi), ii) genitive masculine noun (rabbi) and iii) the third person masculine plural possessive pronoun (him). The latter came in the perfect verb yushrikūn [associate others with their Lord], highlighted the factual action that happens at the same time with the previous action mentioned, or a daily habit. The notion of adversity is spotted by the term \{durrun\} in Q30:33, al-Qurțubi explained it as qaḥtun [lack of rain; dryness], shiddah [adversity] and marad [illness]. Similarly, the term \{sayyi'atun\} in Q30:36 is indicated as another form of bala' [adversity] and cuqūbah [punishment] (al-Qurțubi , 1993, p. 23 - 24). As a sequence, Q30:34 continued:

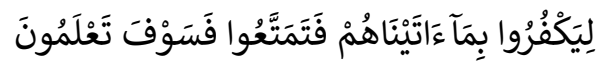

[So that they will deny what We have granted them. Then enjoy yourselves, for you are going to know].

The prefatory part of Q30:34 asserts the rationale of their future punishment because of their ingratitude for the favors God has bestowed on them: Liyakfurū bima atainahum fatamattacū fasawfa taClamūna [So that they will deny what We have granted them. Then enjoy yourselves, for you are going to know]. The Quran implied the lexical impression [Enjoy] with Tamattac (Q39:8) and fatamattacū (Q30:34) ironically. 
INTERNATIONAL JOURNAL OF ACADEMIC RESEARCH IN BUSINESS AND SOCIAL SCIENCES

Vol. 10, No. 7, July, 2020, E-ISSN: 2222-6990 @ 2020 HRMARS

Therefore, the current study infers that the term insan in the next following Quranic samples may be referring to a disbeliever, unbelievers, hypocrites, and so forth. This reflects the leitmotif of monotheism as a tenet of faith.

\section{Example 2: Q39:8 -9}

Q39:8 read,

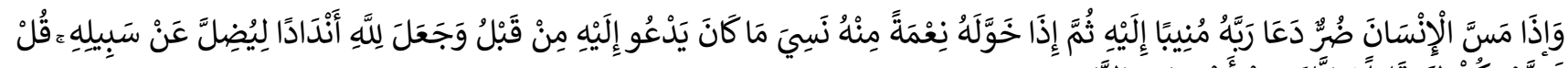

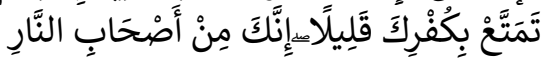

[And when adversity touches man, he calls upon his Lord, turning to Him [alone]; then when He bestows on him a favor from Himself, he forgets Him whom he called upon before, and he attributes to Allah equals to mislead [people] from His way. Say, "Enjoy your disbelief for a little; indeed, you are of the companions of the Fire."]

The notion of human in Q39:8 is signified by the term al-Insan in the form of the accusative masculine noun, means disbeliever. It is understood from these following phrases:

1. wa jacala lillahi andadan liyudilla can sabilihi [and he attributes to Allah equals to mislead [people] from His way. The expression means set up rivals to Allah like idol etc.

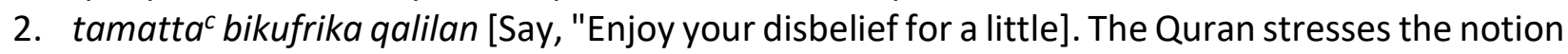
of the unbeliever by the expression kufrika [your disbelief]. This phrase warns the disbelievers of the notion of reward and punishment. The implementation of the term qalilan is as an alert tone: that the enjoyment of the worldly life is but little compared to the eternal Hereafter.

3. The last section innaka min așhabi al-nar synchronizes the connotation of the previous term qalilan, which nailed the notion of severe punishment at the end of Q39:8. The word așhabi al-nar is dedicated to the companion of the Fire who will remained there forever.

The term durr in Q39:8 points out unpleasant things that happened to humans which could be physically, financially and family matters. Despite human is created forgetfulness, the phrase \{nasiya ma kana yad'u 'ilayhi\} [he forgets Him whom he called upon before] does not allude to nature of human creation. This, moreover, is to specify the emotional response of humans when showered with God's favor. Correspondingly, Q10:12 reported: [...he continues [in disobedience] as if he had never called upon Us to [remove] an affliction that touched him]. Seemingly, Q39:9 cites:

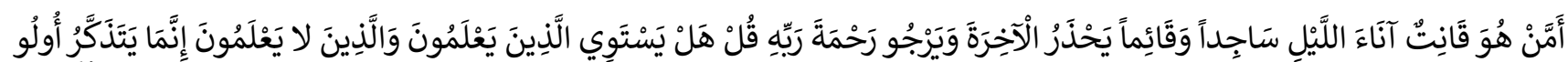
الْالََْبَابِ

[Is one who is devoutly obedient during periods of the night, prostrating and standing [in prayer], fearing the Hereafter and hoping for the mercy of his Lord, [like one who does not]? Say, "Are those who know equal to those who do not know?" Only they will remember [who are] people of understanding].

Q39:8 and Q39:9 are related conceptually by the notion of faith, which is highlighted by the classification of humans into two categories: i) those who know, and ii) those who do not know. The plus and minus signs ( + and - ) are utilized to represent the notion of "Do act" and "Do not act" respectively, as exemplified by Table 1 . 
INTERNATIONAL JOURNAL OF ACADEMIC RESEARCH IN BUSINESS AND SOCIAL SCIENCES Vol. 10, No. 7, July, 2020, E-ISSN: 2222-6990 @ 2020 HRMARS

Table 1. Comparison between believer and disbeliever

\begin{tabular}{|c|c|}
\hline "Those who know" & "Those who do not know" \\
\hline $\begin{array}{l}\text { (+) worships God during the night, } \\
\text { prostrating and standing. }\end{array}$ & $\begin{array}{l}\text { (-) worships God during the } \\
\text { night, } \\
\text { prostrating and standing. }\end{array}$ \\
\hline $\begin{array}{l}(+) \text { have fear of the Day of } \\
\text { Judgment } \\
(+) \text { have hope in the mercy of his } \\
\text { Lord? }\end{array}$ & $\begin{array}{l}(-) \text { have fear of the Day of } \\
\text { Judgment } \\
\text { (-) have hope in the mercy of his } \\
\text { Lord? } \\
\text { (-) turning to God in adversity } \\
(-) \text { turning away from God in } \\
\text { favor }\end{array}$ \\
\hline
\end{tabular}

Accordingly, the Quran interrogates its reader the Rhetorical question: "Are those who know equal to those who do not know?", before the endowment of "Those who know" with the title people of understanding.

\section{Example 3: Q39:49-52}

It is noticeable that Q39:49 provides us with a brief synopsis of the human emotion in adversity and their response in the face of it was to file some supplication to God. Also, it expresses how fast human behavior changed when granted with luxurious worldly life, they turned to be a boastful one. An ungrateful human when they reach on top of the world has been deceived by the favor bestowed from God when they nominated it as sustenance with so-called 'Knowledge':

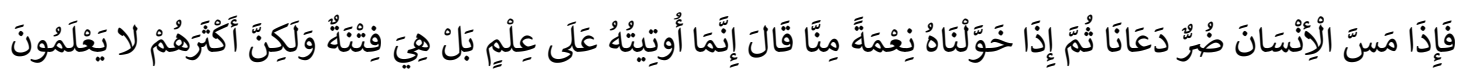

[And when adversity touches man, he calls upon Us; then when We bestow on him a favor from Us, he says, "I have only been given it because of [my] knowledge." Rather, it is a trial, but most of them do not know].

On the grammatical level, the person shift is highlighted from the emergence of al-Insan as thirdperson, to the first-person plural [We- Us] in $d a^{c}$ ana [he calls upon Us] and khawwalna [We bestow], then to first-person [I]. Boasting reaction of human is remarked indirect speech ['innama 'ūtituhū cala cilmin\}["I have only been given it because of [my] knowledge."]. Finally, it shifts back to the human being as a community by third person masculine plural possessive pronoun $\{$ hum $\}$ and third person masculine plural imperfect verb $\left\{y a^{c} / a m u ̄ n\right\}$.

Accordingly, the human is admonished by a throwback reminder of the consequences of the previous nation that is believed to be referred to Korah and his people, indicated by Q39:50-51. Intertextually, the same notion is linked to Q28:78. The connection between Q39:49 and the next two ayahs underlaid in one same theme: the notion of punishment is applied to wrongdoers at any time of centuries, till the Day of Resurrection.

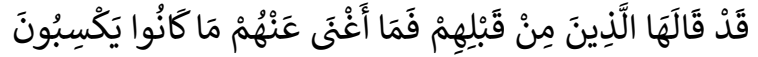

Q39:50: [Those before them had already said it, but they were not availed by what they used to earn].

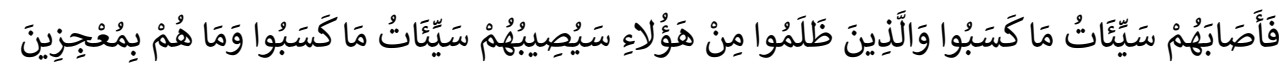


INTERNATIONAL JOURNAL OF ACADEMIC RESEARCH IN BUSINESS AND SOCIAL SCIENCES

Vol. 10, No. 7, July, 2020, E-ISSN: 2222-6990 @ 2020 HRMARS

Q39:51: [And the evil consequences of what they earned struck them. And those who have wronged of these [people] will be afflicted by the evil consequences of what they earned; and they will not cause failure].

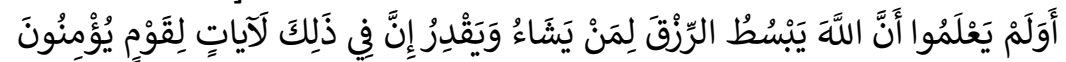

Q39:52: [Do they not know that Allah extends provision for whom He wills and restricts [it]? Indeed, in that are signs for a people who believe].

Lexically, the adversity \{durrun\} in Q39:49 refold poverty and disease (al-Razi, 2008c, p. 287). This definition is parallel to Q39:52, by the emergence of the term al-rizq [provision].

\section{Example 4: Q10:11 and Q10:12}

The term al-insan in the Quran is not necessarily meant to a disbeliever, however, it is assigned as a believer, as Q84:6 cited. Notwithstanding, al-insan in Q10:12 attributes disbeliever for the reason of the action they practiced does not apply to an attitude of a believer (al-Razi, 2008a, 53-54). Q10:12 read,

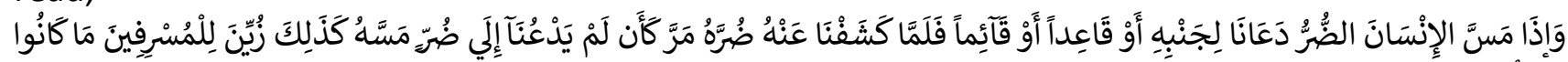

يَعْمَلُونَ

[And when affliction touches man, he calls upon Us, whether lying on his side or sitting or standing; but when We remove from him his affliction, he continues [in disobedience] as if he had never called upon Us to [remove] an affliction that touched him. Thus, is made pleasing to the transgressors that which they have been doing].

Three situations of supplication [i) lying on his side, ii) sitting, or iii) standing] verified the continuous human action in supplication, as well as an act of exaggeration. Ironically, when humans suddenly quit doing so, it is exceptional. On the phrase level \{wa 'idha massa al-Insan\}, prefixed conjunction wa (and) time adverb 'idha is meant for a future time. The phrase ffalamma kashafna\} narrates the past tense. This approved the time frame of this ayah may refer to the past and the future. Also, it linked us to the occurrence of human psychological trait and their behavior, as previously Q10:11 recites:

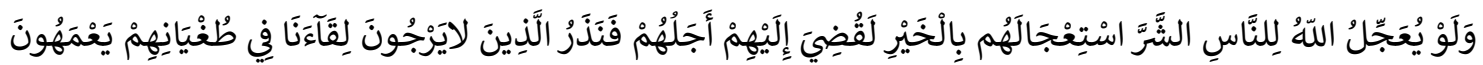
[And if Allah was to hasten for the people the evil [they invoke] as He hastens for them good, their term would have been ended for them. But We leave the ones who do not expect the meeting with Us, in their transgression, wandering blindly]

\section{Example 5: Q41:49-51.}

Three consecutive ayahs in one particular surah may refold human emotions in time of calamity, and how do they respond as such. Let us start with Q41:49:

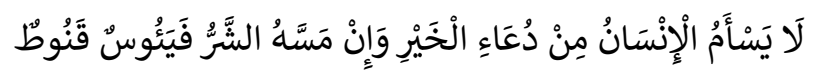

[Man is not weary of supplication for good [things], but if evil touches him, he is hopeless and despairing].

The Quran describes human behavior in doing persistence supplication by the prefatory part of Q41:49: La yas'amu al-Insanu min $d u^{\prime} a^{\prime} i$ al-khayr, [Man is not weary of supplication for good [things]], regardless of his responses after being afflicted by hardship, [but if evil touches him, he is hopeless 
and despairing]. The verb La yas'amu comes in the future tense. This to affirm the continuous action of humans which relates to the psychological trait. The final part of Q41:49 reveals the emotion $Y a^{\prime} \bar{u} s$ translated as [Hopeless], Qanūt is another word for [Despairing]. Intertextually, the same leitmotif of despairing Qanūț appeared in the final part of Q30:36 in the structure of three items: i) surprise particle $\{i d h a\}$, ii) third person masculine plural personal pronoun $\{h u m\}$, and iii) third person masculine plural imperfect verb \{yaqnațuna\}, means [immediately they despair].

Interestingly, Q41:49 expresses two important matters: i) the hyperbole of emotions $Y a^{\prime} \bar{u}$ and Qanūt, built morphologically in $f a^{c} u ̈ l$, ii) kind of al-takrir [repetition]. Emotion $Y a^{\prime} \overline{u s}$ [Hopeless] is in heart unseen, but the impact of Qanüt [Despairing] is explicitly discovered in face and body gesture (al-Razi, 2008d, p. 137). This associate with the facial expression of emotion as studied by Ekman (1993). In the next ayah, Q41:50 affirmed the situation of human during mercy:

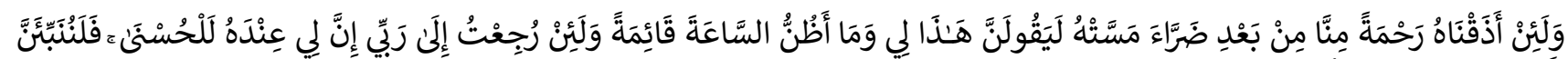

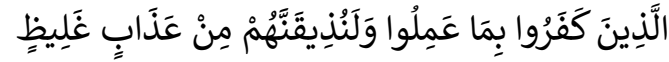

[And if We let him taste mercy from Us after an adversity which has touched him, he will surely say, "This is [due] to me, and I do not think the Hour will occur; and [even] if I should be returned to my Lord, indeed, for me there will be with Him the best." But We will surely inform those who disbelieved about what they did, and We will surely make them taste a massive punishment.]

The occurrence of the semantic embellishment of a shift in both tense and person is observed in Q41:50. The tense shift is presented by the occurrence of the past tense (أَذََّّْاهُ- We let him taste),

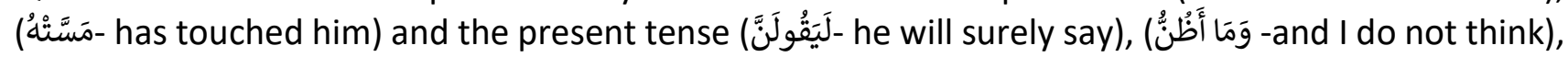

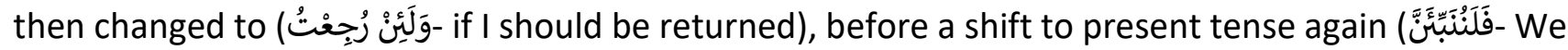

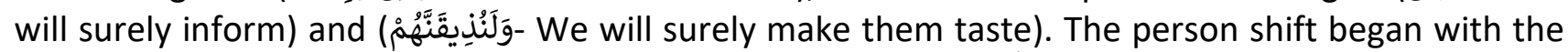

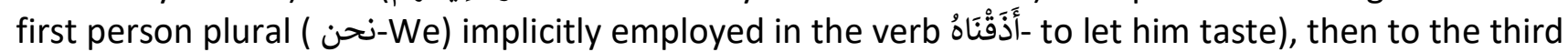

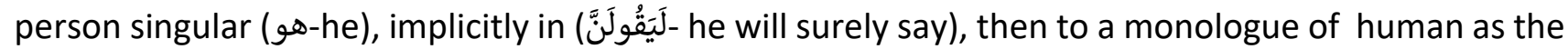
first person singular (IأI) who boasted, "This is [due] to me, and I do not think the Hour will occur; and [even] if I should be returned to my Lord, indeed, for me there will be with Him the best." Q41:50

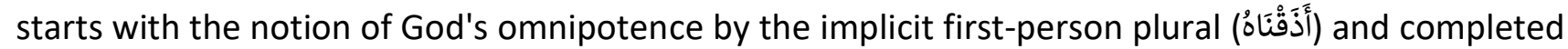
again with the implicit first-person plural (وَلَنْذِيقَتَنَهُمْ

Q41:51 read,

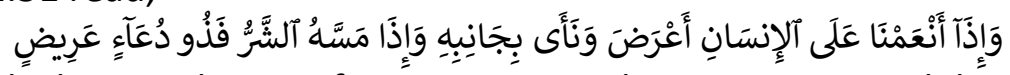

[And when We bestow favor upon man, he turns away and distances himself; but when evil touches him, then he is full of extensive supplication]

In Q41:51, a semantic embellishment of antithesis is acknowledged between $a^{c}$ rada wa na'a bijanibihi [he turns away and distances himself] and the phrase $d u^{c} a$ 'in $a^{c}$ rid [full of extensive supplication]. The underlying meaning of the verb ( $\left.a^{c} r a d a\right)$ is to turn aside and withdraw himself from God's will. Meanwhile, the phrase $\left(d u^{c} a\right.$ 'in $a^{c}$ rid $)$, however, may denote 'turn back in the reverse direction with prolonged supplication. 


\section{Example 6: Q11:9-10}

The disbelievers in the time of hardships tend to be impatient. On the contrary, in prosperity, they turned to be ungrateful. On the grammatical level, Figure 1 exhibits the notion of human emotion in Q11:9-10 as the following pattern: Pattern ('inna - accusative particle) + (hu - third person masculine singular object pronoun $)+($ lam al-tawkìd $(J)$ - emphatic prefix $)+([$ Emotion 1$]-$ nominative masculine singular indefinite noun) + ([Emotion 2] - nominative masculine singular indefinite adjective.

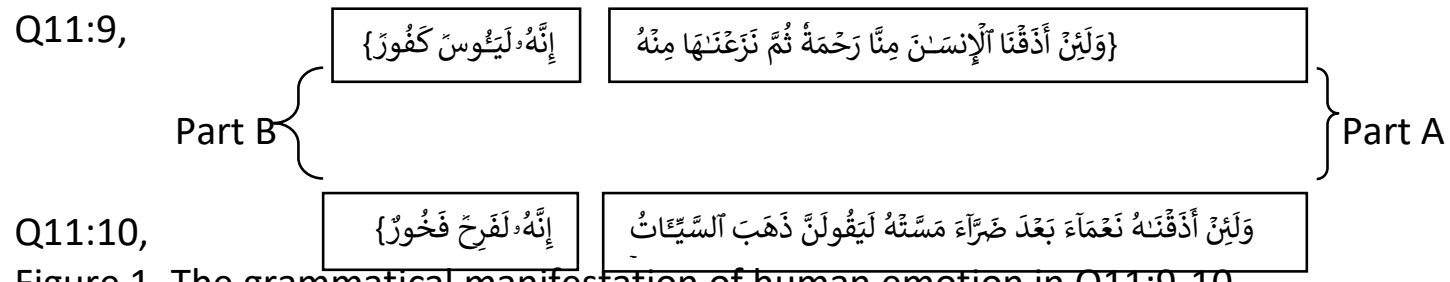

Figure 1. The grammatical manifestation of human emotion in Q11:9-10

Both part B in Figure 1 delivers the human emotion in calamity. The first emotion in Q11:9, term $Y^{\prime} \bar{u} s$ [Despairing] denotes a man who is desperate from the mercy of God. The second emotion Kafūr [Ungrateful] completed the meaning with being ungrateful and thankless. Rhetorically, both terms built on the pola of $f a^{c} \bar{u} l$, exaggerate their meaning, known as hyperbole. The term $Y a^{\prime} \bar{u} s$ denotes an attribute of disbelievers. Intertextually, this notion is referred to Q12:87 \{'innahū la yai'asu min rauhilLahi 'illa al-qawmu al-kafiruna \}[...Indeed, no one despairs of relief from Allah except the disbelieving people]. Similarly, in Q11:10, the first emotion Farihun [Exultant] accompanying the second emotion Fakhūr [Boastful] denotes emotion exaggeration or hyperbole.

If we notice from part B, the stylistic pattern in both Q11:9 and Q11:10 is structurally identical. The structure of 'Innahū lafariḥun fakhūr in Q11:10 is identical to 'Innahū laya'ūsun kafūr in Q11:9. Both ayahs are emphasized by two particles: i) the particle inna and $h u$ as the third person masculine singular object pronoun, and ii) the particle lam or emphatic prefix lam, connected to emotion 1 and emotion 2 in both ayahs respectively. Both terms strengthen the meaning of human being despair and unthankful.

There are two underlying meanings for the term al-Insan in Q11:9 [And if We give man \{al-Insan\} a taste of mercy from Us and then We withdraw it from him, indeed, he is despairing and ungrateful]. The first connotation concerns humans in general; ergo, the addressee is meant to both disbeliever and believer. Specifically, Q11:11 pertains to the believers, precisely in their behavior in the adversity, as cited,

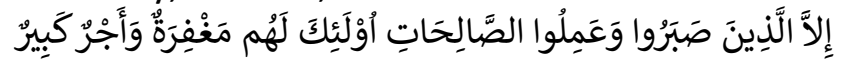

[Except for those who are patient and do righteous deeds; those will have forgiveness and great reward].

On the phrase level, the phrase $\{a$ l-ladhina șabarū\} denotes those who show patience in the hardships. Meanwhile, the phrase $\left\{w a^{c}\right.$ amilu al-șalihat $\}$ appertains to those who are grateful in the favor. The phrase \{'ula'ika lahum maghfiratun wa 'ajrun kabir\} nails the notion of reward and punishment, as the phrase \{'ula'ika lahum maghfiratun\} means being saved from the bad times, while the phrase $\{w a$ 'ajrun kabir\} is a victory for good deeds (p. 200). Accordingly, the restriction particle $\{i l l a\}$ [Except] in prefatory part of Q11:11 represents the coherence between two previous ayahs, Q11:9 and Q11:10. Likewise, Q11:9 and Q11:10 distinguish the attribute of disbelievers. Conversely, 
INTERNATIONAL JOURNAL OF ACADEMIC RESEARCH IN BUSINESS AND SOCIAL SCIENCES Vol. 10, No. 7, July, 2020, E-ISSN: 2222-6990 @ 2020 HRMARS

Q11:11 summarized the perseverance of believers and their good deeds, and the reward they will have in return. Thematically, the notion of human emotion in Q11:9-10 is conceptually and intertextually related to Q70:19-21.

Besides, we observe the circle of adversity when it affected human from the underlying meaning of part $A$, then this circle confirms of the continuous activity of human behavior in the face of pre-during and post adversity:

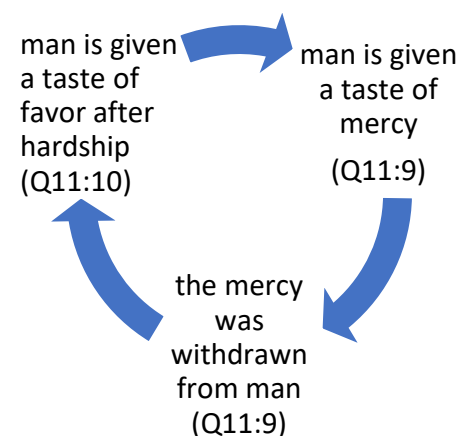

Figure 2. A circle of human behavior in adversity

Intertextually, in the same tone from the Quran, Q14:34 agreed: [And He gave you from all you asked of Him. And if you should count the favor of Allah, you could not enumerate them. Indeed, mankind is [generally] most unjust and ungrateful \{'Inna al-insana laẓalūmun kaffarun\}.

\section{Example 7: Q70:19-21}

As aforementioned in Example 5, Q11:9-10 is conceptually linked to this sample. Three consecutives ayahs in the same surah represent the connection between response and trait. Q70:19 indicated human psychological trait with anxiety through the emergence of particle \{'inna\}, إِنَّ الإنَسَانَ خُلِقََ هَلُوعًا 19 [The man was created anxious]. Then, human response to adversity is elaborated in Q70:20 and Q70:21, in the same stylistic formula but opposite thematically, as in Figure 3.

This section answers the third question: Is there any relationship between human responses in adversity with the human psychological trait? The answer is: yes. Human responses are related to human psychological trait as portrayed by the following discussion:

Q70:20 read: [When evil touches him, impatient,].

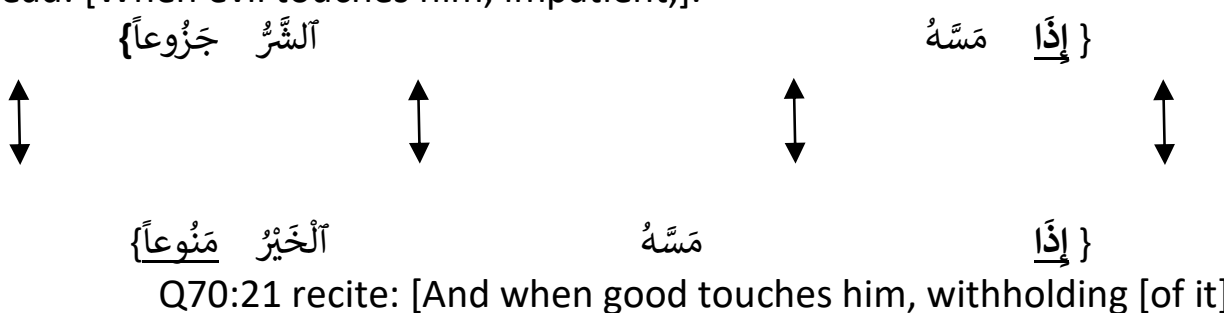

Figure 3: Lexical embellishment in consecutives ayahs in one same surah

The term jazü $\bar{u}^{c}$ an [impatient] in Q70:20 is paralleled to the next ayah, Q70:21 \{manü $\left.\bar{u}^{c} a n\right\}$ [withholding [of it]], as we notice an equal similarity in terms of the number or words and the stylistic itself. Assonance can be seen in Q70:19 \{halücan\}, Q70:20 \{jazücan\} and Q70:21 \{manücan\}, retold a "mode 
INTERNATIONAL JOURNAL OF ACADEMIC RESEARCH IN BUSINESS AND SOCIAL SCIENCES

Vol. 10, No. 7, July, 2020, E-ISSN: 2222-6990 @ 2020 HRMARS

of lexical embellishment refers to the agreement in the last letters of two propositions (Abdul-Raof, 2006, p. 260).

The Quran informed us about the psychological traits of the human individual which usually occurs in the form of a passive verb khuliqa (is created), which mirrors the character and attitude of the human male and female being. On the macro-level analysis, more samples recurrent elsewhere throughout the Quran, as in Q4:28 [And Allah wants to lighten for you [your difficulties]; Mankind was created weak] \{...wa khuliqa al-insanu dacifan\}, Q21:37 Man was created of haste \{khuliqa alinsanu min 'ajal\} I will show you My signs, so do not impatiently urge Me]. In the form of a passive verb, those very brief ayahs provided its reader with in-depth psychological details about the behavior and attitude of the human such as 'anxiety', 'impatience', and 'haste'.

\section{Example 8: Q17:11, 67, 83 and 100}

Another relationship between human responses with the human psychological trait is encountered in a surah level in Q17: 11, 67, 83, and 100. Quranic stylistics offer a semantic function of continuity by the verb kana, literally meaning (was). The verb kana signifies continuity and applies to all times, people, and regardless of their geographical places or time. Through the meanings of the verb kana, it extracts interesting details about the behavior of the human character.

1) The expression ' $a j u \overline{l a n}$ in Q17:11 Wa kana al-insanu ${ }^{c} a j u \overline{l a n}$ [Man \{the human being\} is ever hasty], indicates the psychology of the human individual, male and female. In terms of Quranic exegesis, the word al-insan here refers to Adam during his creation, and before the rūh (spirit) has reached his feet; the newly created human being is in a hurry and cannot wait to stand up. Thus, the expression 'ever hasty' confirms one of the characteristic features of the psychological behavior of the descendants of Adam (al-Zarkashi, 1988, p. 145; al-Razi, 2008b, p. 164; Ibn Kathir, 1986, p. 27).

2) The expression kafüran in Q17:67 by the phrase Wa kana al-insanu kafüran [And ever is man ungrateful].

3) The expression ya'ūsan in Q17:83 by the phrase kana ya'ūsan [he is ever despairing].

4) Q17:100 Wa kana al-insanu qatūran [And ever has man been stingy]. The word qatūran means bakhil manücan (stingy and niggardly). Ibn Kathir also relates Q17:100 thematically to Q70:19-21. (1986, p. 67).

\section{Pattern 2: Conceptual and Intertextual Chaining within Quranic surahs}

As aforementioned in Pattern 1, the previous section has discussed the notion of coherence occurred in the theme of human emotion in affliction by micro textual analysis in the Quranic discourse. In this section, the discussion will explore the notion of connectedness, consistency, and relevance within the Quranic surahs, exploring the emotional and behavioral responses of humans in hardships. In the same tone, this study will demonstrate how these ayahs correlated conceptually and intertextually. In other words, this pattern investigates coherence in a given Quranic surah within the Quran as a whole, as exemplified by Example 1 [Q10:12, Q30:33, Q39:8, and Q39:49]; Example 2: Q17:83, and Q41:51; and Example 3 [Q30:36, and Q42:48].

Example 1: Q10:12, Q30:33, Q39:8, and Q39:49

To begin, let us start with Q10:12. It is divided into two parts: 
INTERNATIONAL JOURNAL OF ACADEMIC RESEARCH IN BUSINESS AND SOCIAL SCIENCES Vol. 10, No. 7, July, 2020, E-ISSN: 2222-6990 @ 2020 HRMARS

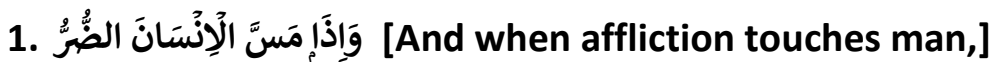

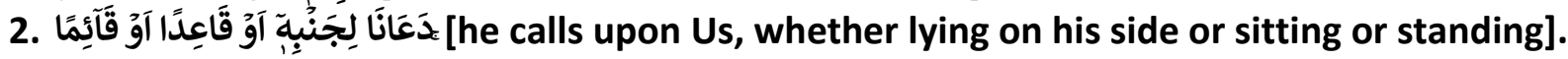
The introductory part is thematically alluded to by Q10:21 but in different grammatical and stylistic structures. On the second macro level which is the whole Quranic text, the leitmotif of the final part of Q10:12 occurs in Q30:33, Q39:8, and Q39:49, as exemplified by Table 1. Table 1 below described human reaction and emotion in affliction in another two Quranic surahs by the pattern of same leitmotifs with an almost similar stylistic presentation. One of the human responses during affliction is to make supplication to God.

Table 1: Same leitmotifs with almost similar stylistic presentation

\begin{tabular}{|c|c|c|}
\hline $\begin{array}{l}\text { QURANIC } \\
\text { TEXT }\end{array}$ & PREFATORY PART & FINAL PART \\
\hline Q30:33 & 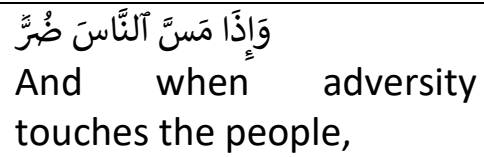 & 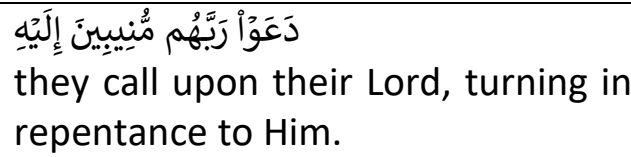 \\
\hline Q39:8 & 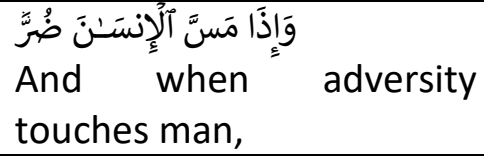 & $\begin{array}{l}\text { دَعَا رَبَّهُ مُنِيباً إِلَيِْه } \\
\text { he calls upon his Lord, turning to Him } \\
\text { [alone] }\end{array}$ \\
\hline Q39:49 & 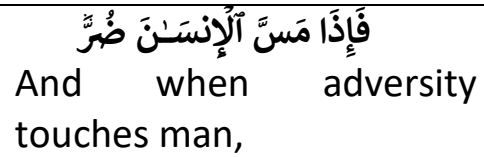 & $\begin{array}{l}\text { دَانَانَ } \\
\text { he calls upon Us }\end{array}$ \\
\hline
\end{tabular}

Thematically, Table 1 with three samples (Q30:33, Q39:8, and Q39:49) signifies one same leitmotif: In the time of humans is touched by adversity, their responses are to make supplication to God. The gist of these samples is assisted by a semantic signal. In this section of human reaction to obstacles, this semantic signal is a useful linguistic tool in the textual analysis of Quranic discourse, a term that hints the occurrence of hardship, and it usually appears before the adversity takes place. On the lexical level, the expression massa [to touch] appeared before the keyword $d-r-r$ [adversity] as illustrated in Table 1. The prefatory part of each sample shares similar stylistic presentation with slight differences by the particle waw in Q30:33, and Q39:8; or particle $f a^{\prime}$ at the first letter in Q39:49.

On the grammatical level, the final part explicates human reaction to obstacles from the past tense of $d a^{c} a$ [to call upon] with slight changes to the numbers of the person involved. Q10:12, Q39:8, and Q39:49 referred to third person masculine singular perfect verb, with an exception for Q30:33 in the grammatical form of plural noun $d a^{c} a u$ rabbahum munibina ilayhi. It connotes of disbelievers from the form of third person masculine plural in these terms: (i) perfect verb in $d a^{c} a u$, (ii) possessive pronoun in rabbahum, and (iii) accusative active participle in munibina. How it related to the faith is described by the form of third person masculine singular object pronoun in ilayhi, which denotes [to Him (God)]. We observe the final part of Q39:49 is the simplest reaction of human prayer without further description of body gesture. Both Q30:33 and Q39:8 added some extra response by [turning in repentance to $\mathrm{Him}]$, which are almost identical in terms of syntactic presentation.

On the phrase level, intertextually, the phrase \{nasiya ma kana yad ${ }^{\top} \bar{u}$ ilayhi min qablu\} he forgets Him whom he called upon before] in Q39:8 is similarly chained to the phrase in Q10:12 \{Marra ka'an 
INTERNATIONAL JOURNAL OF ACADEMIC RESEARCH IN BUSINESS AND SOCIAL SCIENCES

Vol. 10, No. 7, July, 2020, E-ISSN: 2222-6990 @ 2020 HRMARS

lam yad'una 'ila durrin massahu \}[he continues [in disobedience] as if he had never called upon Us to [remove] an affliction that touched him].

\section{Example 2: Q17:83, and Q41:51}

Human reaction and emotion in affliction are described by a comparison between two ayahs from two different Quranic surahs. The following discussion portrays the time-related comparison of two situation of human responses: during the time of adversity, and during indulging God's favor. In other words, is there any changes in human behavior if they are granted with God's favor first, then after human is being tested with affliction. Interestingly, the Table 2 brings forward the responses of humans in two temporal times: during favor of acceptance from God, and during being tested in adversity as exemplified by Q17:83, and Q41:51 respectively.

We know the occurrence of anthesis in Table 2 from two antonyms semantic signals. The prefatory part of Table 2 with the expression 'an'amna [We bestow favor] hints the implicit occurrence of rahmah [favor]. As alluded in Table 1, the final part of Table 2 displays the expression massa [to touch], that appeared before the keyword sh-r-r [adversity].

Table 2: A comparison of human responses between two ayahs from two Quranic surahs

\begin{tabular}{|c|c|c|}
\hline $\begin{array}{l}\text { Quranic } \\
\text { text }\end{array}$ & $\begin{array}{l}\text { Human response during acceptance } \\
\text { of God's favor }\end{array}$ & $\begin{array}{l}\text { Human response during } \\
\text { adversity }\end{array}$ \\
\hline Q17:83 & 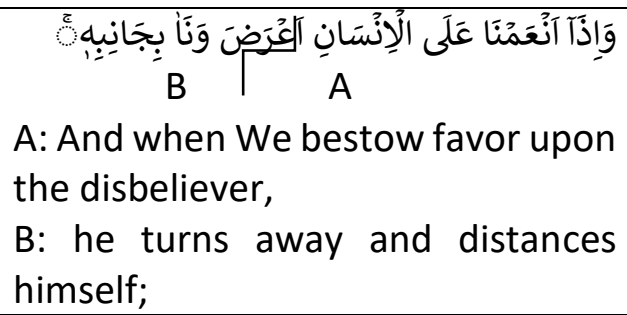 & 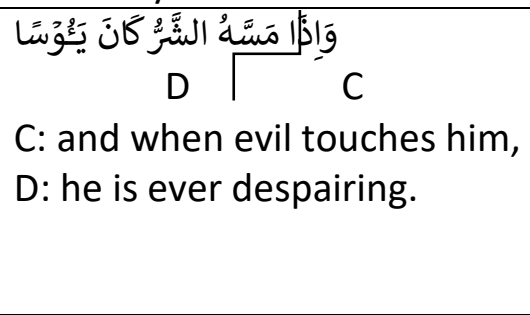 \\
\hline Q41:51 & 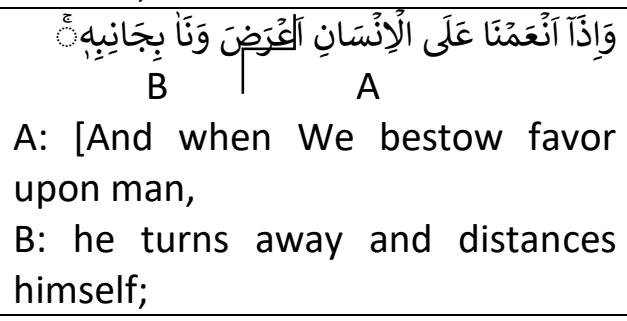 & 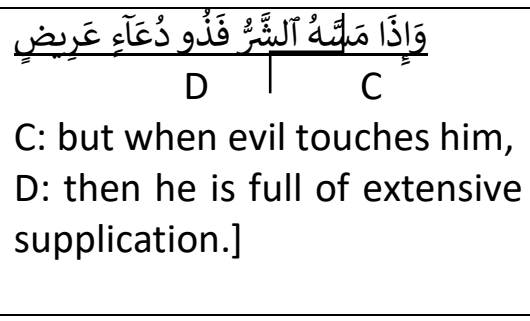 \\
\hline
\end{tabular}

It is noted that the Quranic stylistic is implied in the part A, B and C with exactly identical. Thematically, if we divided it into question and answer pattern, it would be like a one-way communication of Quranic presentation that can be divided into four parts: A, B, C and D. In the both part A of Q17:83 and Q41:51 respectively, the Quran stipulated: And when We bestow favor upon man (disbeliever), \{Dear readers, guess what will he response?\} Then in the both part B of Q17:83 and Q41:51 respectively, the Quran acknowledged the answer: \{Definitely human's response is\}: he turns away and distances himself). In the both part C of Q17:83 and Q41:51 respectively, the Quran asserted again: but when evil touches him, \{dear readers, guess what will happen this time?\} The Quran finally responded that the human emotion and his responses in adversity may differ. Either [he is ever despairing] as in Q17:83, or human may be full of extensive supplication] as Q41:51 read. 
This beautiful technique of implicit questioning and answering is suggested quite similar to a mode of semantic embellishment, or rhetorical question. A 'Yes' or 'No' answer is not expected. The most important is its effect to the readers or addressee. In sum, part A, B and C are identical respectively, with exception in part $D$ that is different. Thus, human emotion in the part D of Q17:83 is despair, which provides the answer to the research Question (1). The research Question (2) is replied by Part D of Q41:51 which reflects human make lengthy supplication to God in time of adversity.

\section{Example 3: Q30:36, and Q42:48}

Similar examples are discussed in another two different surahs, on ayahs' level, as exemplified by Table 3. Part A and B in both Q30:36 and Q42:48 respectively is thematically the same, as the Quran make announcement of human happy responses in the favor of God. The different came in the grammatical-morphological structures of human and their numbers. Part $C$ in both Q30:36 and Q42:48, however, spell out the Quranic repetition of formulaic affirmation: wa 'in tușibhum sayyi'atun bima qaddamat aidihim [but if evil afflicts them for what their hands have put forth]. Table 3. A comparison of human responses between Q30:36, and Q42:48,

\begin{tabular}{|c|c|c|}
\hline $\begin{array}{l}\text { Quranic } \\
\text { text }\end{array}$ & $\begin{array}{l}\text { Human response during } \\
\text { God's favor }\end{array}$ & $\begin{array}{l}\text { Human response during } \\
\text { adversity }\end{array}$ \\
\hline Q30:36 & 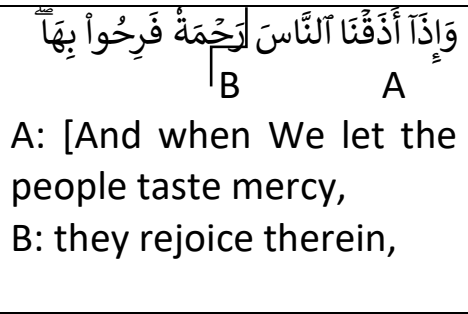 & 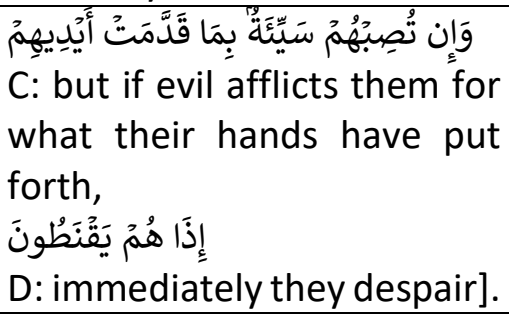 \\
\hline Q42:48 & 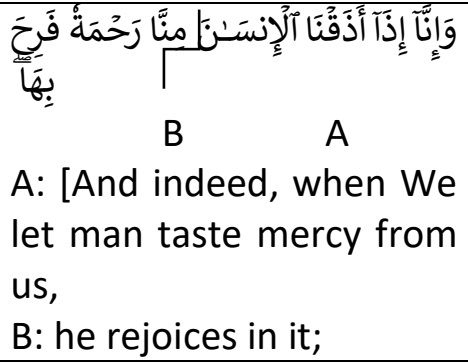 & 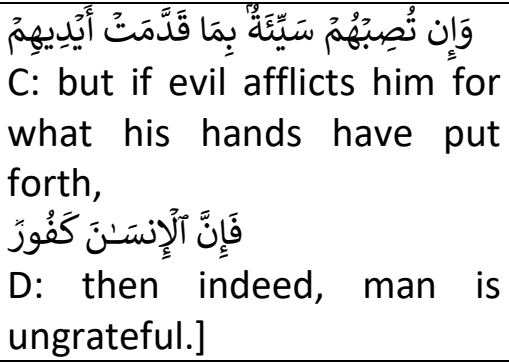 \\
\hline
\end{tabular}

The Quranic formulaic affirmation explained that 'human is the bane of his own coins, thus the cause of his own problems'. On the macro level analysis, intertextually, this meaning is supported by Q3:182, Q8:51, Q22:10, and Q62:7, when the Quran affirmed that:

1) Q3:182: [That is for what your hands have put forth and because Allah is not ever unjust to [His] servants."]

2) Q8:51: [That is for what your hands have put forth [of evil] and because Allah is not ever unjust to His servants."]

3) Q22:10: ["That is for what your hands have put forth and because Allah is not ever unjust to [His] servants."]

4) Q62:7: [But they will not wish for it, ever, because of what their hands have put forth. And Allah is Knowing of the wrongdoers]. 


\section{Pattern 3: Conceptual and Intertextual Chaining at Co-Textual Level}

Co-textual level of discourse concerns grammatical-lexical forms in one sentence. The significant of co-text is highlighted throughout this study ini the previous discussion implicitly in the two prior Pattern 1 and Pattern 2. Since co-text is " a major linguistic factor that plays a significant role in the realization of coherence in Quranic discourse" (Abdul-Raof, 2005, p. 301), due to space limitation, this study only elaborate one sample to be analyzed: Q42:48 cite,

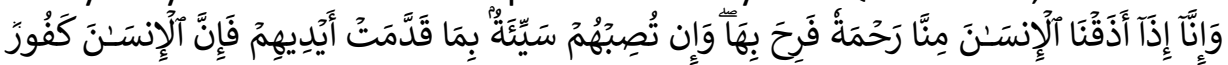

[And indeed, when We let man taste mercy from us, he rejoices in it; but if evil afflicts him for what his hands have put forth, then indeed, man is ungrateful.]

Q42:48 explains: Pattern (inna - accusative particle) + (al-insan - accusative masculine noun) + (kafürun - nominative masculine singular indefinite adjective). It is noted that the accusative particle inna [indeed] is one of the common emphasizers encountered in the Quran. More emphasizers are such as: actually, certainly, clearly, definitely, obviously, surely and etc. (Quirk et al, 1973, p. 214215). The impact of adversity to human emotion kafür [ungrateful] and their relationship is clearly depicted by [then indeed, man is ungrateful] by the occurrence of particle $f a$, means [then], followed by the particle 'inna [indeed]. Thus, Fa 'inna al-insan kafür is the Quranic affirmation of this kind of human emotion that exist in reality.

\section{Coherence and Textual Progression}

The current study agreed with Abdul-Raof (2005, p. 256), as he asserted:

"... the text is made up of multi-layered thematic compartments which are conceptually and intertextually correlated. The intertextual relationship among the various leitmotifs of various compartments also plays a significant role in the process of textual progression. A coherent discourse needs to display textual progression in order to be textually acceptable."

Undeniably, adversity make an impact to what human feel, and on how human behave and react to hardships. These multi-layered thematic compartments endorsed by the Quranic points of view in random order are as follows: [ the emergence of adversity- Quranic stand towards an issue- Human response either emotionally or behaviorally - the significant of God's favor ]. The leitmotivs are manisfested in one single ayah, that represent by these particular thematic patterns in Table 4 and Table 5.

This is described by Table 4 and Table 5 with indicators as below:

1. The Plus (+) symbol means 'being given something' and the minus (-) symbol refers to 'something being removed'.

2. The character A defines Adversity. Thus, A (+) signifies 'Adversity touches man', and A (-) signifies 'Adversity is removed'.

3. The characters GF symbolizes 'God's Favor'. Therefore, GF (+) means 'God gave favor'; and GF (-) indicates 'God withdrew favor'.

4. The characters HR stands for 'Human Response'. The number after HR explains the sequence of the responses: HR1 substitutes for 'Human First Response'; HR2 is for 'Human Second Response'; and HR3 is for 'Human Third Response'. 
INTERNATIONAL JOURNAL OF ACADEMIC RESEARCH IN BUSINESS AND SOCIAL SCIENCES

Vol. 10, No. 7, July, 2020, E-ISSN: 2222-6990 @ 2020 HRMARS

5. The characters QR corresponds to 'Quran response'. The number after QR explains the sequence of the responses: QR1 for 'Quran First Response'; and QR2 expresses 'Quran Second Response'.

In Table 4, Pattern A begins with a firm statement about human, laid down by the Quran. Next, adversity occurred, and finally, human response is detected. Pattern B mentions adversity first, then human reveals his emotion. Pattern $\mathrm{C}$ also begin with adversity.This triggers human repost. Then, when God grants favor, suddenly human counterresponse. Pattern D is almost similar to Pattern C, with additional Quranic response at the end. This pattern is exemplified by two samples from two different surahs, as in Q17:67 and Q39:49. Pattern E reflects to three human response: one emotional response in adversity, two behavioral responses in time of indulgence that eleborate the characteristics of disbelievers, before the Quran confirmed their destiny permanently. Pattern $F$ compares human responses between two temporal times: in time of hardship, and after the hardship is withdrawn. As usual, the Quran took over and responded.

Table 4. The multi-layered thematic compartments in Pattern A, B, C, D, E and F.

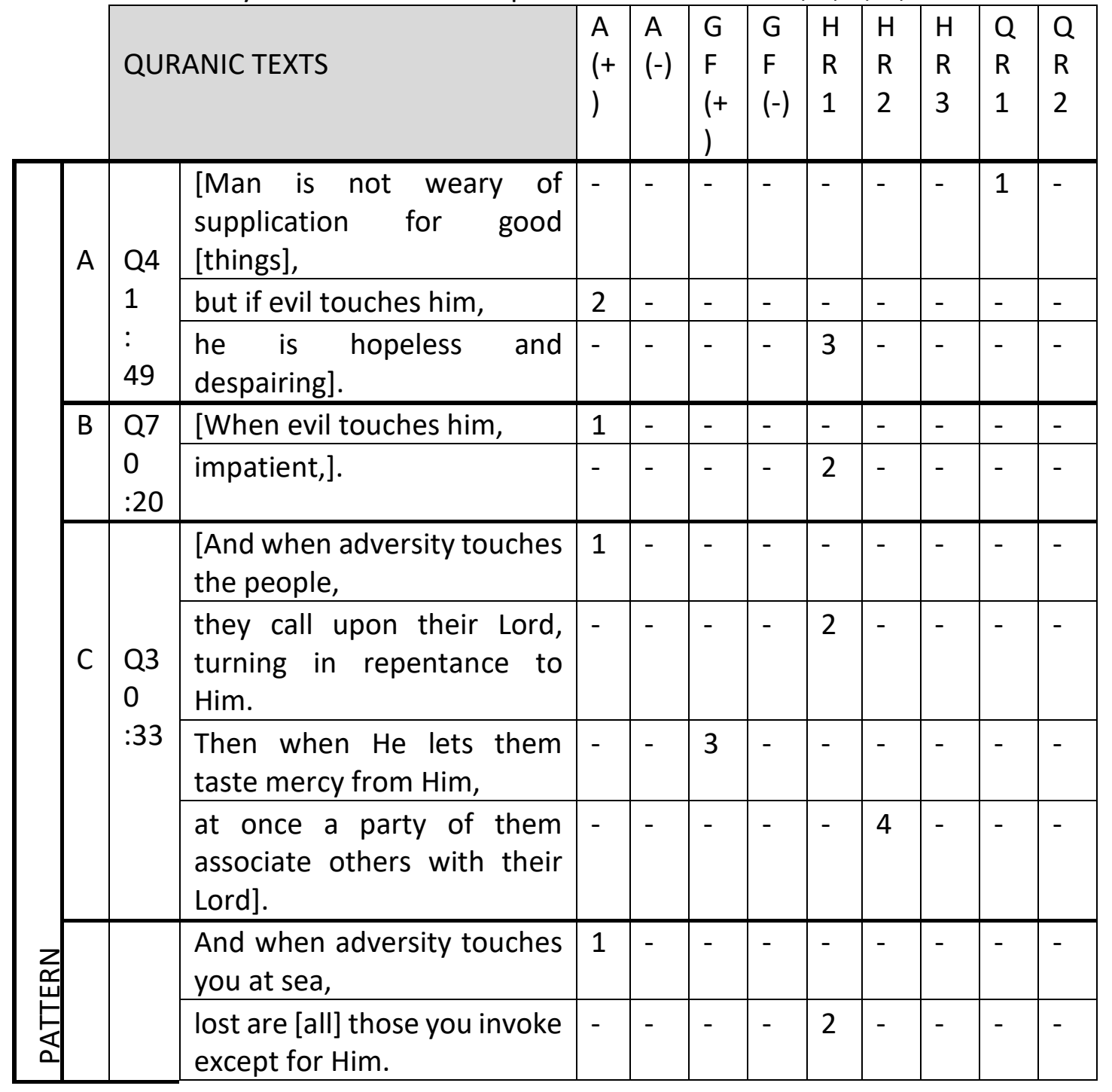




\begin{tabular}{|c|c|c|c|c|c|c|c|c|c|c|c|}
\hline \multirow[t]{8}{*}{ D } & \multirow{3}{*}{$\begin{array}{l}\text { Q1 } \\
7 \\
: 67\end{array}$} & $\begin{array}{l}\text { But when He delivers you to } \\
\text { the land, }\end{array}$ & - & - & 3 & - & - & - & - & - & - \\
\hline & & you turn away [from Him]. & - & - & - & - & - & 4 & - & - & - \\
\hline & & And ever is man ungrateful. & - & - & - & - & - & - & - & 5 & - \\
\hline & \multirow{5}{*}{$\begin{array}{l}\text { Q3 } \\
9 \\
: 49\end{array}$} & $\begin{array}{l}\text { And when adversity touches } \\
\text { man }\end{array}$ & 1 & - & - & - & - & - & - & - & - \\
\hline & & he calls upon Us; & - & - & - & - & 2 & - & - & - & - \\
\hline & & $\begin{array}{l}\text { then when We bestow on } \\
\text { him a favor from Us, }\end{array}$ & - & - & 3 & - & - & - & - & - & - \\
\hline & & $\begin{array}{l}\text { he says, "I have only been } \\
\text { given it because of [my] } \\
\text { knowledge." }\end{array}$ & - & - & - & - & - & 4 & - & - & - \\
\hline & & $\begin{array}{l}\text { Rather, it is a trial, but most } \\
\text { of them do not know. }\end{array}$ & - & - & - & - & - & - & - & 5 & - \\
\hline \multirow{6}{*}{$E$} & \multirow{6}{*}{$\begin{array}{l}\text { Q3 } \\
9 \\
: 8\end{array}$} & $\begin{array}{l}\text { [And when adversity touches } \\
\text { man, }\end{array}$ & 1 & - & - & - & - & - & - & - & - \\
\hline & & $\begin{array}{l}\text { he calls upon his Lord, } \\
\text { turning to Him [alone]; }\end{array}$ & - & - & - & - & 2 & - & - & - & - \\
\hline & & $\begin{array}{l}\text { then when He bestows on } \\
\text { him a favor from Himself }\end{array}$ & - & - & 3 & - & - & - & - & - & - \\
\hline & & $\begin{array}{l}\text { he forgets Him whom he } \\
\text { called upon before, }\end{array}$ & - & - & - & - & - & 4 & - & - & - \\
\hline & & $\begin{array}{l}\text { and he attributes to Allah } \\
\text { equals to mislead [people] } \\
\text { from His way. }\end{array}$ & - & - & - & - & - & - & 5 & - & - \\
\hline & & $\begin{array}{l}\text { Say, "Enjoy your disbelief for } \\
\text { a little; } \\
\text { indeed, you are of the } \\
\text { companions of the Fire."] }\end{array}$ & - & - & - & - & - & - & - & 6 & - \\
\hline \multirow{4}{*}{$F$} & \multirow{4}{*}{$\begin{array}{l}\text { Q1 } \\
0 \\
: 12\end{array}$} & $\begin{array}{l}\text { And when affliction touches } \\
\text { man, }\end{array}$ & 1 & - & - & - & - & - & - & - & - \\
\hline & & $\begin{array}{l}\text { he calls upon Us, whether } \\
\text { lying on his side or sitting or } \\
\text { standing; }\end{array}$ & - & - & - & - & 2 & - & - & - & - \\
\hline & & $\begin{array}{l}\text { but when We remove from } \\
\text { him his affliction, }\end{array}$ & - & 3 & - & - & - & - & - & - & - \\
\hline & & $\begin{array}{l}\text { he continues [in } \\
\text { disobedience] as if he had } \\
\text { never called upon Us to } \\
\text { [remove] an affliction that } \\
\text { touched him. }\end{array}$ & - & - & - & - & - & 4 & - & - & - \\
\hline
\end{tabular}


INTERNATIONAL JOURNAL OF ACADEMIC RESEARCH IN BUSINESS AND SOCIAL SCIENCES Vol. 10, No. 7, July, 2020, E-ISSN: 2222-6990 @ 2020 HRMARS

\begin{tabular}{|l|l|l|l|l|l|l|l|l|l|l|l|}
\hline & $\begin{array}{l}\text { Thus is made pleasing to the } \\
\text { transgressors that which } \\
\text { they have been doing. }\end{array}$ & - & - & - & - & - & - & - & 5 & - \\
\hline
\end{tabular}

Table 5.The multi-layered thematic compartments in Pattern $\mathrm{G}, \mathrm{H}, \mathrm{I}, \mathrm{J}, \mathrm{K}$ and $\mathrm{L}$.

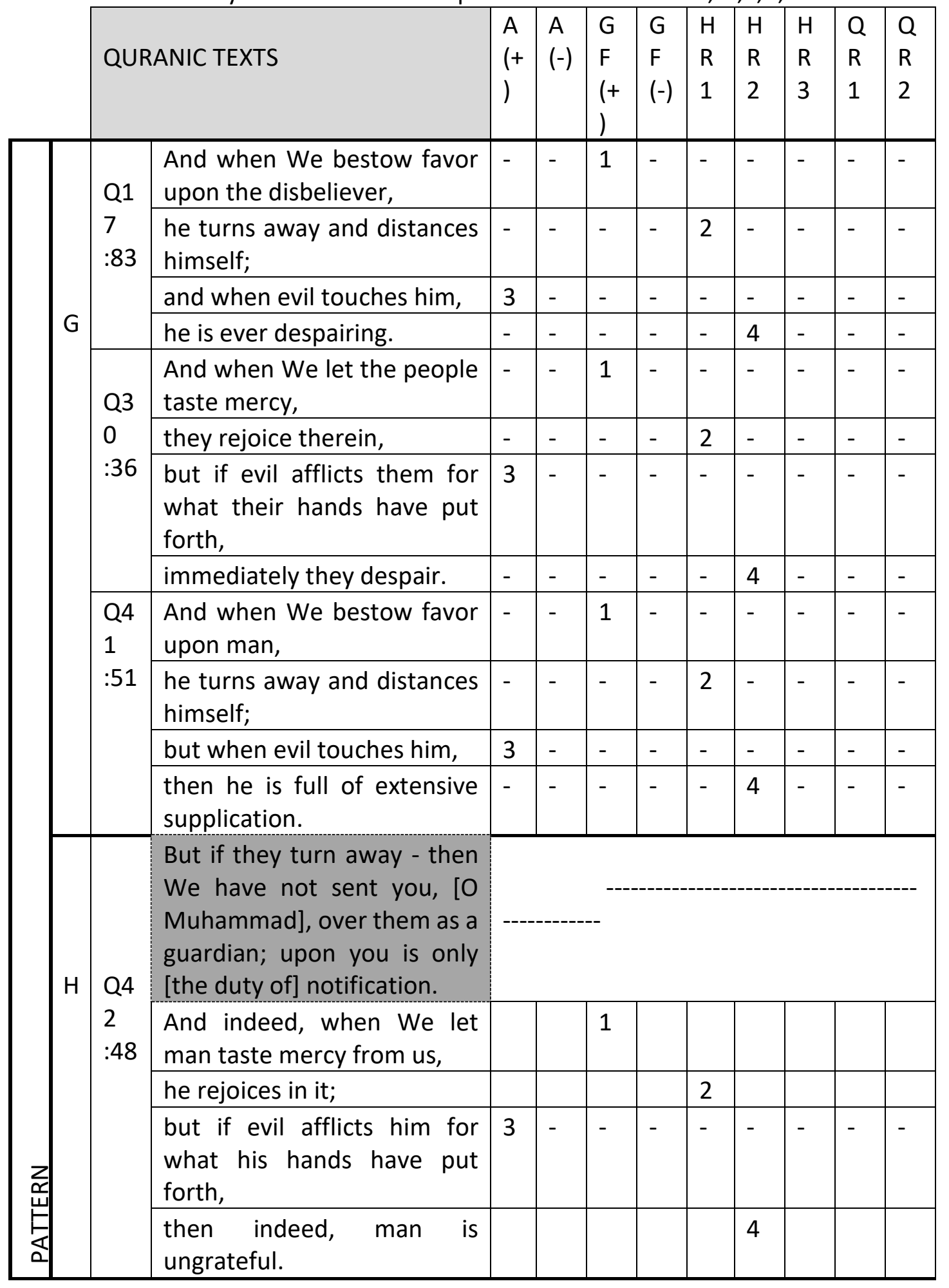


INTERNATIONAL JOURNAL OF ACADEMIC RESEARCH IN BUSINESS AND SOCIAL SCIENCES Vol. 10, No. 7, July, 2020, E-ISSN: 2222-6990 @ 2020 HRMARS

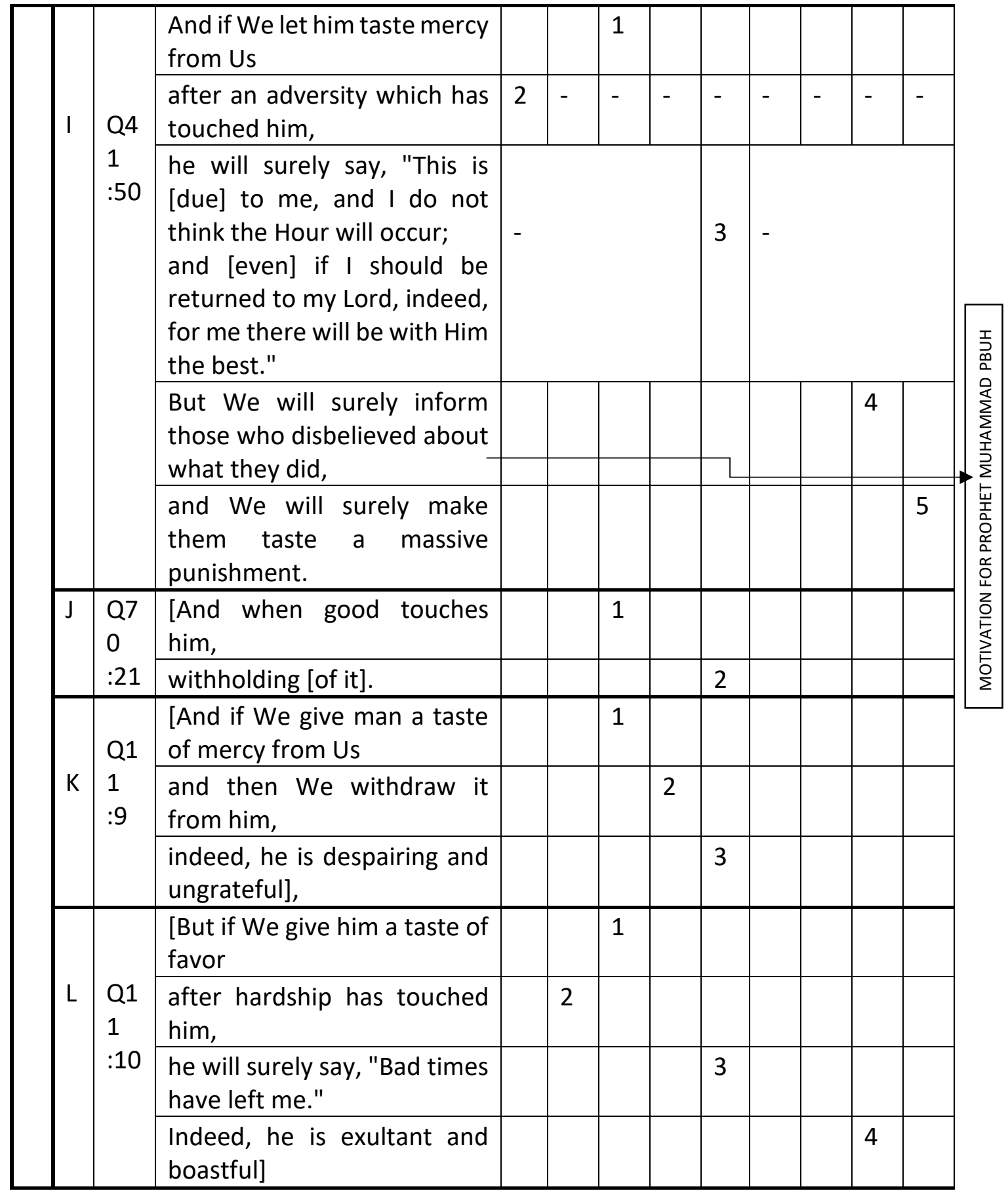

Interestingly, Pattern G, Pattern I, Pattern J, Pattern K and Pattern L share one common thing in the prefactories of each pattern: the affirmation of God's favor to human is noted before mentioning the behavioral responses of human toward happiness. Suddenly, as soon as calamity afflicts human, these behavioral responses of human changed on the contrary. Like a short story in the outer bigger frame of Quranic stories, Pattern $\mathrm{H}$ is the only structure that began with motivation to Prophet Muhammad PBUH. Pattern I displays multiple responses from the Quran reflecting to the notion of God's omnipotence. The disbeliever's rejection in human direct speech, is seen in Q41:50. On syntax and morphology level, the emphatic prefix lam is applied three times in the ayah: once as third person 
INTERNATIONAL JOURNAL OF ACADEMIC RESEARCH IN BUSINESS AND SOCIAL SCIENCES

Vol. 10, No. 7, July, 2020, E-ISSN: 2222-6990 @ 2020 HRMARS

individual [he] for describing disbeliever action layaqūlanna [he will surely say]; twice as first-person plural [We] in falanunabbi 'anna [But We will surely inform those who disbelieved], and first-person plural [We] in walanudhiqannahum [and We will surely make them taste].

\section{Conclusion}

Throughout the previous discussions, the study reached at the following conclusions:

1. On the word level of analysis of this study, coherence is achieved through parallel structures in the grammatical and morphological level. Also, on the ayah level, the notion of repetition is encountered throughout the study with the assistance of transitional devices, to show similarity and agreement, for the purpose of reasoning, to contradict, or as a consequence etc.

2. Based on the textual analysis of Quranic discourse, the notion of human in this present study is mostly referred to as disbeliever, which appointed by co-hyponyms of disbelievers such as the term \{al-musrifina\} [transgressors] in Q10:12.

3. Based on the semantic analysis, there are certain semantic signals in the Quran which hint the human responses in adversity explicitly by behaviors as follows:

1) On the verb level, as \{'acradtum\} [you turn away [from Him]] in Q17:67, and \{acrada\} [to turn away] as in Q41:51.

2) On the phrase level, as $\left\{a^{c}\right.$ rad $a$ wa $\left.n a^{\prime} a\right\}$ [he turns away and distances himself] in Q17:83 and Q41:51.

3) Human haste is confirmed by the prohibition particle $\{l a\}$ [do not] involving second person masculine plural imperfect verb in jussive mood \{tastaciliūni\} [impatiently urge $\mathrm{Me}]$, as in Q21:37.

4. The semantic signals for the emergence of adversity is indicated as follows:

1) On the lexical level, as exemplified by three expressions: i) \{al-durru\} in $Q 10: 12 ;\{$ durrun\} in Q30:33, Q39:8, Q39:49; \{darra'a\} in Q11:10, Q41:50; ii) \{al-sharru\} in Q17:83, Q41:49, Q41:51, Q70:20; and iii)\{sayyi'atun\} in Q30:36, Q42:48; \{al-sayyiatu\} in Q11:10.

2) On the phrase level, by $\mathrm{Q} 4: 28,\left\{y u k h a f f i f u{ }^{c}\right.$ ankum $\}$ [to lighten for you [your difficulties]], and Q11:9, \{nazacnaha minhu\} [We withdraw it from him].

5. In adversity, predominantly, human responses by making supplication to God as in Q41:51, which is conceptually and intertextually related to Q10:12, Q30:33, Q39:8, and Q39:49 in Pattern 2 with the same thematic referral.

6. In God's favor, however, human responded to happiness is encountered in direct speech, which relates these responses to human psychological traits, as proud and boast emotion in Q39:49 and Q41:50.

7. The dominant 'basic' human emotions in time of calamity in the study as encountered in the Quran are as follows: ungrateful in (Q17:67) and (Q42:48); despair in (Q17:83) and (Q30:36); despairing and ungrateful in (Q11:9); hopeless and despairing in (Q41:49); make lengthy supplication in (Q41:51); exultant and boastful in (Q11:10) and impatient in Q70:20.

8. God recognition of human emotion in adversity is described conceptually and intertextually by three major patterns:

1) Conceptual and Intertextual Chaining at Inter Ayah Level 
INTERNATIONAL JOURNAL OF ACADEMIC RESEARCH IN BUSINESS AND SOCIAL SCIENCES

Vol. 10, No. 7, July, 2020, E-ISSN: 2222-6990 @ 2020 HRMARS

2) Conceptual and Intertextual Chaining within Quranic surahs

3) Conceptual and Intertextual Chaining at Co-Textual Level

9. The relationship between emotions and psychological traits of human is examined through the grammatical- morphological analysis as manifested by the following:

1) The manifestation of the Passive Verb khuliqa to Human Psychological Traits.

2) The manifestation of verb kana to Human Psychological Traits.

10. Thematically, the textual progression and chaining of Quranic ayahs prove that the tenets of faith such as the leitmotif of monotheism, and the leitmotifs of reward and punishment are noticed throughout the discussion.

11. For future research in the Quranic Coherence Discourse, the study suggests the methodology in the investigation of Quranic text shall be applied through the analysis of Thematic Progression Pattern as an adding value to explore the coherent relation of Theme-Rheme in texts.

\section{Contribution}

The main contribution of this study is that it can be delivered into two areas of knowledge under one roof: i) psychology, and ii) linguistic. From the psychological point of view, to understand human is to interpret human emotion and their responses coping with adversity. With no doubt, human responses are connected to a human psychological trait. Linguistically, this can be explained from the framework of Quranic discourse with the assistance of Quranic lexicography, Quranic Arabic Corpus, and Quranic exegetes. Thus, it is understood that the compilation of these subfields of knowledge provides us with a new perspective of how the Quran demonstrated human emotion, admitting their normal physiological responses, human body reaction to the emotion, and the way human behaves in response to the emotion itself. In the end, it may respond to the emergence of the thematic structural coherence of human emotion in the selected Quranic texts. The most important is, the Quranic Coherence Discourse is parallel to the Psychology in terms of understanding human emotions, and at the same time seeking for the resilience in a time of catastrophe.

\section{References}

'Abd al-Baqi, M. (2007). 'al-Mu'jam al-Mufahras li-Alfaz al-Qur'an al-Karim wifqa nuzūl alkalimah (5th ed.). Beirut: Dar al-Ma'rifah.

Abdul-Raof, H. (2004). Qur'anic stylistics: A linguistic analysis. Lincom Europa.

Abdul-Raof, H. (2005). Consonance in the Qur'an: A conceptual, intertextual and linguistic analysis. Lincom Europa.

Abdul-Raof, H. (2006). Arabic Rhetoric. A Pragmatic Analysis. Routledge.

Al- Razi, F. A. D. (2008a, October 15). Mafatih al-Ghaib [al-Tafsir al-Kabir]. Retrieved from https://ia802607.us.archive.org/6/items/FPtrazitrazi/trazi17.pdf

Al- Razi, F. A. D. (2008b, October 15). Mafatih al-Ghaib [al-Tafsir al-Kabir]. Retrieved from

Al- Razi, F. A. D. (2008c, October 15). Mafatih al-Ghaib [al-Tafsir al-Kabir]. Retrieved from

Al- Razi, F. A. D. (2008d, October 15). Mafatih al-Ghaib [al-Tafsir al-Kabir]. Retrieved from

Alimah (5th ed.). Beirut: Dar al-Ma'rifah.

al-Qurțubi (1993). al-Jamic li-Ahkam al-Qur'an. (10 Vols). Beirut: Dar al-Kutub al-cllmiyyah. 
INTERNATIONAL JOURNAL OF ACADEMIC RESEARCH IN BUSINESS AND SOCIAL SCIENCES

Vol. 10, No. 7, July, 2020, E-ISSN: 2222-6990 @ 2020 HRMARS

Al-Zarkashi, A. (1988). al-Burhan fi Ulūm al-Qur'an (Vol. 1, pp. 204-207). Beirut: Dar al-Kutub alIlmiyyah.

Bauer, K. (2017). Emotion in the Qur'an: An Overview. Journal Of Qur'anic Studies, 19(2), 1-30.

De Beaugrande, R. \& Dressler, W. U. (1981). Introduction to Text Linguistics. Longman.

Dukes, K. (2009). The Quranic Arabic Corpus. http://corpus.quran.com. University of Leeds.

Ekman, P. (1993). Facial expression and emotion. American Psychologist, 48(4), 384-392. doi:10.1037/0003-066x.48.4.384

Ekman, P. (1999). Basic emotions. In T. Dalgleish \& M. J. Power (Eds.), Handbook of cognition and emotion (p. 45-60). John Wiley \& Sons Ltd. https://doi.org/10.1002/0470013494.ch3

Galadari, A. (2013). The Role of Inter-Textual Polysemy in Qur'anic Exegesis. Quranica: International Journal on Quranic Research, 3(4), 35-56.

Halliday, M. A. K. \& Hasan R. (1976). Cohesion in English. London: Longman. https://ia802607.us.archive.org/6/items/FPtrazitrazi/trazi20.pdf https://ia802607.us.archive.org/6/items/FPtrazitrazi/trazi26.pdf https://ia802607.us.archive.org/6/items/FPtrazitrazi/trazi27.pdf

Ibn Kathir (1986). Tafsir al-Qur'an al-`Ażim: wa-yalih kitab faḍa'il al-Qur'an. (Vol. 3). Beirut: Dar alFikr.

Khawaldeh, S. (2017). Analysis of the Quranic Text Using intertextuality: A Case Study of Two Lexemes. Advances in Language and Literary Studies, 8(5), 89-98.

Quirk, R., Greenbaum, S. (1973). A University Grammar of English. New York: Longman.

Saheeh International. (1997). The Quran: Arabic text with Corresponding English Meanings. Almunatada Allslami.

SM, R. A., \& SM, H. M. (2011). The Quran as Intertext: A Critical Reflection. Canadian Social Science, $7(5), 43-50$.

Sulaiman, S. (2011). Textual, Syntactic, and Semantic Analysis of Qur'anic Parables [Unpublished doctoral dissertation]. University of Leeds.

Van Dijk, T. A. (1980). The semantics and pragmatics of functional coherence in discourse. Speech act theory: Ten years later, 49-65.

Wang, Y., \& Guo, M. (2014). A short analysis of discourse coherence. Journal of Language Teaching and Research, 5(2), 460. 